\title{
The choice of the EPC contract model text research in China
}

\author{
Ningming $\mathrm{Xu}$
}

Tianjin University of technology school of management

Keywords: EPC, contract model text

\begin{abstract}
EPC is a new mode of project construction, has become the development trend of engineering construction market. Engineering general contracting mode development relatively late in our country, in 2011 to develop a corresponding contract model of the construction project engineering general contract demonstration text (try out) ". In this paper, the international engineering general contracting a comparison of several common con-tracts, aims to explore the general contract of construction project engineering demonstration text (try out) "the applicability in China.
\end{abstract}

\section{THE EPC MODE ESSENCE}

\subsection{International EPC mode}

The AIA think EPC and DB, there is no essential difference between is a kind of DB only deformation; FIDIC think EPC, unlike the DB, is an extension of DB contract way. Design, procurement and construction (EPC) : academic definition of EPC mode is not unified, there are generally two kinds of views: the first kind of view is that its different from the DB mode, is' design + construction $(\mathrm{D}+\mathrm{B})$ an extension "the way of contract, the content covered by EPC, the contractor may request for the owners to provide according to the contract including project financing, land purchase, design, construction, equipment procurement, installation and debugging until the completion of a full range of services". The second argument is that no essential difference between EPC and DB, but more emphasis on the importance of "purchase" in the project, mainly used in process design and procurement of large complete sets of equipment of the important position of industrial construction sector, such as chemical industry, metallurgical project; and the DB is mainly used for housing construction project and other civil engineering field. Now only international FIDIC Fan Benzhong will EPC words included in the formal contract, and deformation of the AIA think EPC is the DB.

\subsection{China EPC mode essence}

EPC is a kind of engineering general contracting mode, do not belong to the engineering project management mode, and EPC general contracting can undertake project management business on different projects. According to the "about the development of engineering general contracting and project management enterprise guidance" (built city no. 30 [2003]) article 2: the main engineering general contracting design procurement construction (EPC)/key-delivered general contracting, design, construction general contracting (D, B), and according to the different size, type, and the owner of the project requirements, also can be used in design, procurement of the general contractor general contracting $(\mathrm{E}-\mathrm{P})$, procurement, construction general contracting $(\mathrm{P}-\mathrm{C})$, etc. The design procurement construction general contracting refers to the engineering general contracting enterprises in accordance with the stipulations of the contract to undertake the project engineering design, procurement, construction, commissioning services, such as work, and about the quality of the contracted projects, security, time limit for a project, the construction cost will be entirely responsible for. Turnkey contractor is an extension of the design procurement construction general contracting business and responsibility, finally is submitted to the owner a meet use function, the conditions of use of the project.

Built the city no. 30 [2003] : specified in article 3 of the engineering project management refers to the enterprises engaged in project management (hereinafter referred to as the project management enterprise) authorized by the owner, in accordance with the stipulations of the contract on be- 
half of the owner to the whole process of project implementation of management and service of several stages.

Built the city no. 30 [2003] stipulated in article 4: can be entrusted by the owner of the general contractor enterprise, in accordance with the contract agreement, undertake project management business, but should not be on the same project at the same time to undertake engineering general contracting and project management business, and nor should undertake engineering general contracting or project management business enterprises with the other party of subordination or other interest relationship.

\section{EPC CONTRACT COMMONLY USED}

\section{1 conditions of contract for EPC/turnkey projects}

FIDIC is the abbreviation of "international federation of consulting engineers", French FIDIC contract conditions is widely used throughout the world. Published in 1999, a series of new standard contract FIDIC conditions of contract conditions for construction of the new red book, new beige book "production equipment and design - construction contract conditions", the new silver leather book design - procurement - construction/turnkey contract conditions ", the new green paper concise contract format. Not only can be used in civil engineering, the new red book can also be used for mechanical and electrical engineering; Belong to the traditional model, provide the design by the owner, the contractor is responsible for equipment materials, procurement and construction supervision consulting engineers, valuation, according to the drawing according to the actual quantity settlement, unforeseen conditions and price changes allow pricing; Is a kind of owner participate and control more, take risks and more contract model. New beige book intermingled with the 1987 version of the Yellow Book "electrical and mechanical engineering contract conditions" and the 1995 version of the orange peel book design - build and turnkey contract conditions. Under the new beige book, is the basic obligation of the contractor to complete the permanent equipment design, manufacture and installation; Applicable to the contractor is responsible for equipment procurement, design and construction, supervision, consulting engineers fixed price, but unforeseen conditions and price changes can pricing; Is a kind of owner to control the more general contract model. Silver leather book is really correspond to the original book of orange peel engineering general contract template, borne by the contractor for all design, procurement and construction, until the production operation; Lump sum total contract price, in addition to the force majeure condition, other risks are borne by the contractor; Sent on behalf of the management project owner, final results, only very little step in the process of project implementation, is a complete project general contracting mode. Green paper is mainly suitable for lower value or simple form, or repetitive, or time of building and civil engineering.

FIDIC in 1995 version of the book of orange peel, 1999 new beige book and silver leather book all the words in the DB or EPC/Turnkey, suitable for fixed price engineering general contracting mode, DB and EPC/Turnkey and there is no essential difference, so the difference between the FIDIC new beige book and silver leather book lies not in the engineering construction pattern, but rather in the sharing and application of the engineering type of risk.

\subsection{The AIA design - construction contracts}

AIA is The American Institute of Architects (The American Institute of Architects), AIA series published by The contract documents in The international project contracting industry, especially in The americas has The high authority, wide application.

Engineering general contracting mode about start construction market in the United States in the $70 \mathrm{~s}$, the AIA design as early as in 1985 created the first edition - construction contracts, and revised in 1996, and in 2004 created the new contracts. AIA old design - construction contract full text altogether includes three text, respectively A191: standard protocol format, owners and design construction contractors A491: design, construction contractors and construction standard agreement between contractor and B901: design, construction standard agreement between contractor and architect format. 2004 the new expanded to include five text, respectively is: A141: owner and 
design - construction contractor agreement standard format, A142: design, construction contractor and the contractor agreement standard format, B142: owner and consulting agreement standard format (owner to prepare the design - construction mode), B143: design, construction contractor and architect agreement standard lattice type, G704 / DB: design, construction projects substantial completion notice. This article mainly research A141

\subsection{The general contract of construction project demonstrative text (try out)"}

Along with the rapid development of construction industry in our country, gradually with international engineering, the engineering general contracting construction model is becoming more and more prevalent, in order to promote healthy and effective development of the engineering general contracting mode, on November 1, 2011 of housing and urban-rural development in our country, the state administration for industry and commerce jointly compiled by the general contract of construction project engineering demonstration text (try out) ") in force, this is our country by the government department to organize the formulation of the first applies to domestic engineering general contracting contract demonstration text. The general contract of construction project engineering demonstration text (try out) ", to guide, standardize construction engineering general contracting parties to the contract of market behavior, to create a relatively fair and just market environment, safeguard legitimate rights and interests of the parties to a contract, rectify unfair contract format terms, avoid or reduce the contract fraud and disputes will be has the very vital significance.

Demonstrative text by the contract agreement, general conditions and special terms and conditions of three parts: the contract agreement, in accordance with the agreed contract (main) offer and acceptance; General conditions, in accordance with the agreed implementation stage (secondary) offer and acceptance; Special terms, it is according to the situation of different construction project, the related (secondary) offer and acceptance of general terms and conditions and in accordance with the law has made the elaboration, add, modify, improve and shall be separately stipulated.

Some domestic engineering general contract, almost copy of the international federation of consulting engineers (FIDIC) EPC/turnkey project contract conditions, some of the terms and conditions. And conditions of the contract to have the strong case law (British and American law of contract), therefore, there are many in terms of the contract do not accord with the provisions of the law in our country, is one of the causes of some "overlord terms";

principle of contract law, confused cause certain legal liability in the contract. In order to avoid the demonstrative text contract law case law principle difference was caused by some "legal responsibility confused and overlord provision". Therefore, the brief introduction, the main differences between the two kinds of contract law principles here is one of the purposes of. To another, is by introducing two kinds of principles of contract law difference, let everybody to further understand the demonstrative text and FIDIC contract conditions of the EPC/turnkey projects, the main clause. So that everyone understands why can't copy the FIDIC contract conditions to prepare the demonstrative text.

\section{CONCLUSION}

As you can see above, the engineering general contract of construction project contract demonstration text (try out) "with FIDIC differences in risk sharing, and AIA relatively close: FIDIC silver leather book will risk more transferred to the contractor, the AIA and the general contract of construction project engineering demonstration text (try out)".

\section{REFERENCES}

[1]. Michel Crouhy,Dan, Galai/Robert Mark. Risk Management, New York: McGraw-Hill, 2001

[2]. Latham,M., Constructing the Team, Final Report of the joint Government Industry Review of Procurement and Contractual Arrangements in the UK Construction, HMSO, Publication Center, London,1994,36-38 
[3]. Seung H.Han \& James E Diekmann, Approache for making risk-based go no-go decision for international projects, Journal of construction engineering and management, 2001, V ol. 127, No.4, 300-308

[4]. Zhi He, Risk management for overseas construction projects, International Journal of Project Management, 1995, 13(4): 231-237 